\title{
Hydroelectric resources of minor rivers in areas of compact settlement inhabited by low-numbered peoples of the north
}

\author{
Dmitry Nogovitsyn ${ }^{1,}$, Zinaida Sheina ${ }^{1}$, and Ludmila Sergeeva. ${ }^{1}$ \\ ${ }^{1}$ The FBFI Larionov V.P. Institute of Physical and Technical problems of the North, Siberian Branch of the Russian Academy \\ of Science (IPTPN SB RAS) Yakutsk, Russia
}

\begin{abstract}
The article presents the results of expeditionary reconnaissance surveys of minor rivers in the Yana basin that allowed for the first time to estimate the installed capacity of seasonal microhydroelectric power stations for power supply to remote isolated localities. Works on the study of the hydrological characteristics of minor rivers in the territory under consideration have not been carried out before. For the first time, reliable information about the hydrological regime of rivers was obtained. This is primarily water consumption and the longitudinal grade of watercourse being the basis for making a decision on the location, determining the capacity of micro-power plants, as well as choosing the necessary hydroelectric equipment.
\end{abstract}

\section{INTRODUCTION}

Minor rivers on the vast territory of the Republic of Sakha (Yakutia) have been remained underexplored until now. Interest in their use has emerged relatively recently due to the spiraling cost increase of organic fuel and their delivery to the outer remote areas of the region. The monitoring of the hydrological regime of rivers is carried out mainly on large rivers, and a large number of minor rivers running on the territory of the Republic remain largely unexplored. As a result, it is very difficult to determine the hydroelectric potential of minor watercourses. In this regard, field surveys of minor rivers in the North-East of Yakutia were conducted. The article presents the results of full-scale rough surveys of minor rivers to make a decision on the location and the choice of equipment for micro-hydroelectric power plants with the capacity necessary for electricity consumers in remote localities or enterprises with a seasonal nature of operation in the North-East of Yakutia. In the course of field work in 2016, quantitative hydrological characteristics were obtained, as well as data on water flow and the longitudinal slope of tributaries of the Yana and the Tompo Rivers. The studied watercourses of the Ilin-Billeekh stream, the Desovsky, the Stantsiya, the Setynja, and the Dzhuganja brooks belong to the category of minor watercourses of seasonal type. Every year they freeze to the bottom. The catchment area of the rivers under consideration, according to the ratio of hydrological posts per $1 \mathrm{~km}^{2}$, is poorly studied. Work on the study of the hydrological characteristics of minor rivers in the territory under consideration has not been carried out before. The results obtained are fiducial data necessary for identifying the hydroelectric resources of minor rivers and their use in local energy areas in the North-East of the Republic of Sakha (Yakutia). The analysis of the collected material will eventually allow us justifying the cost-effective recommendations for the construction of priority mini-power plants and the creation of a sustainable power supply to consumers in remote localities.

\section{MATERIALS AND RESEARCH METHODS}

To identify priority micro and mini hydro power plants the field work was carried out in the river basin of the Yana River. The power of mini-plants was determined by the formula $\mathrm{N}=9,81 \cdot \mathrm{Q} \cdot \mathrm{H} \cdot \mathrm{\eta}_{\text {турб }} \cdot \eta_{\text {ген }}$, in $\mathrm{kW}$, where $\mathrm{Q}$ is the flow rate of water flowing through hydro turbines of the HPP in $\mathrm{m}^{3} / \mathrm{s}, \mathrm{H}$ is the water head in $\mathrm{m}, \mathrm{\eta}_{\text {турб }}$ is the turbine efficiency, $\mathrm{\eta}_{\text {ген }}$ is the generator efficiency [1].

The hydrological characteristics of the Ilin-Billekh, the Stantsiya, the Setyndzha, the Dzhuganja watercourses, primarily water flows of $\mathrm{Q}$ are determined by the method of calculating them without data from hydrometric observations on SP33-101-2003-M [2]. The calculated water pressure was determined by leveling high water marks, longitudinal water slopes, as well as cross profiles of the minor riverbed and its valley during the rough survey on SP11 -103-97-M [3].

\section{STUDY AREA AND CHARACTERISTIC OF RIVERS}

The research area is located on the territory of Verkhoyansky, Kobyaisky and Tomponsky uluses of the Republic of Sakha (Yakutia), in places of habitat of the small indigenous peoples of the North. In urban settlements, the population is engaged in industrial production, manufacturing, electricity, construction and trade. The rural population mostly preserves the traditional way of life of the peoples of the North.

The territory of the basins of the studied rivers - the Ilin-Billeekh, the Setyndzha, the Dzhuganja and nameless brooks (operating names are the Stantsiya and the Desovsky), qualifies as the large uplands of the North-East of Russia - Verkhoyansk-Chukotka region, the main elements of which are the ancient median massifs and the large-sized bow areas that frame them and represented by a complicated system of anticlinoria and synclinoria.

The first anticline zone is represented by the ranges of the Verkhoyansk chain. These are typically bow areas with an absolute height of 1000-2300 $\mathrm{m}$ [4]. 
The second anticline zone is expressed as the foldedblock chains of the Chersky and plexuses of mountains in the area of the upper Indigirka [4].

Small watercourses on the territory under consideration belong to unexplored objects, Fig. 1.

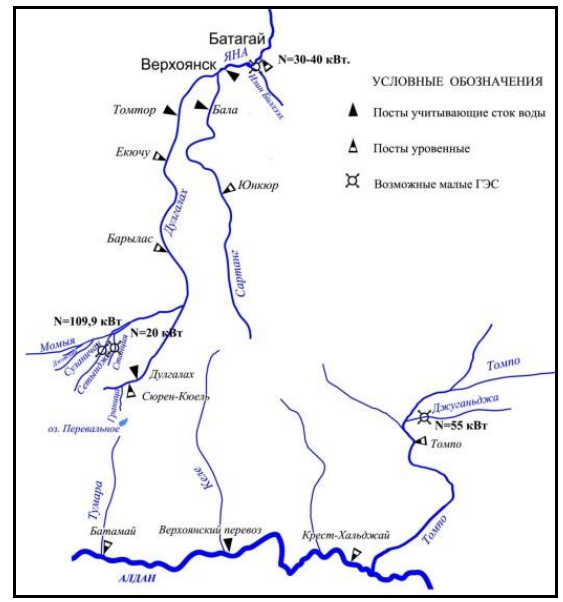

Fig. 1. Layout of hydrological stations and posts on the territory under consideration

The rivers in the territory under consideration are fed mainly by rain and snow, as well as by melting of glaciers and ice. The main flow is carried out in summer. In winter time the rivers freeze to the bottom for $6-8$ months forming numerous glaciers.

In summer, high but short-term rain floods are typical. The minimum runoff occurs in winter season. In winter, the rivers freeze to the bottom forming numerous glaciers. The freezing of minor rivers lasts 6-8 months.

The Ilin-Billekh River. The Ilin-Billekh [5] is a right tributary of the Yana. The research objects are located in Verkhoyansky ulus of the Sakha Republic (Yakutia) - on the territory of $25 \mathrm{~km}$ to South-West of the administrative center of the urban-type settlement of Batagai, $35 \mathrm{~km}$ to East of the city of Verkhoyansk and 4.5-5.0 km to East of Stolby settlement. The study sites are located 100-300 $\mathrm{m}$ apart from each other. There is the Batagai-Verkhoyansk auto-road close to the sections. Fig. 2.

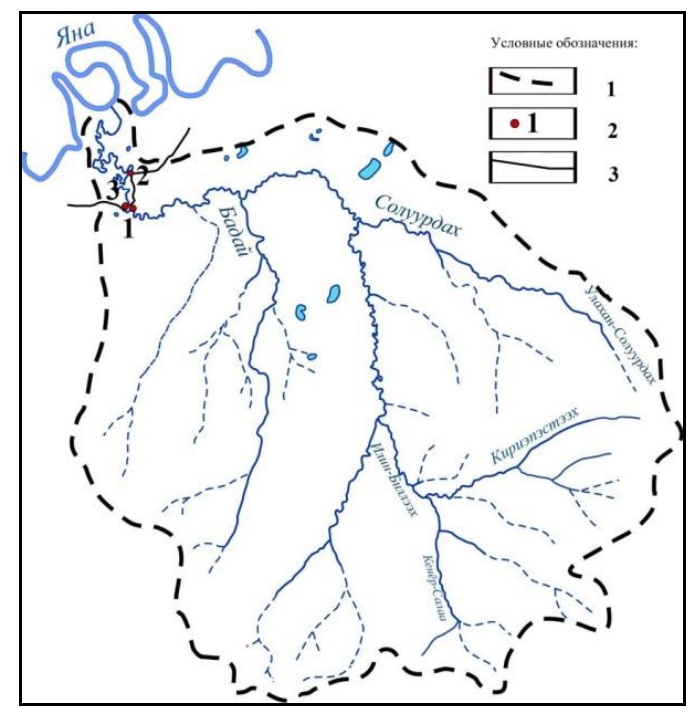

Fig. 2. Scheme of the catchment area of the Ilin-Billekh river: 1 - catchment boundary; 2 - stream gauge; 3 - auto-road.

The territory is located in the Verkhoyansk mountain region within the Yano-Indigirsky tundra-taiga highlands [4]. The terrain is characterized by the combination of plateaus, intermountain areas and relatively low ridges with marks of $\sim 150 \mathrm{~m}$ above sea level according to the Baltic system of height, gently descending to the valley of the Yana River, occupied by the valley of the East Billekh.

The climate of the region is sharply continental. The air is dry. The average annual temperature here is + $15^{\circ} \mathrm{C}$. The average annual precipitation is $150-300 \mathrm{~mm}$ [6]. The lowest amount of precipitation occurs in March and April. The rainiest months are July and August. The territory is located in the permafrost zone, the thickness of which reaches 300-500 $\mathrm{m} \mathrm{[6].}$

Winter is very cold and dry. The winter temperature is extremely low; it drops to $-60^{\circ}$. The duration of the winter season is about seven months. Long-term average January air temperatures in Verkhoyansk are $-49^{\circ}$. The weather is calm, fair with some clouds, rarely interrupted by snowfalls. In the mountains, due to inversion, the air temperature is higher than in the basins and river valleys. In the mountains, where there are strong winds and snowstorms, there is a lot of precipitation [4], and the height of the snow cover reaches $50-90 \mathrm{~cm}$. In depressions, snowstorms are rare and the height of the snow cover does not exceed 25-30 cm [4].

Summer is short. In the intermountain basins, it is quite warm and rainless. On some days, the daytime temperature can reach $+35^{\circ}$. The nights are cool. Throughout the summer season, there are wind-chills and snowfalls [4].

The frost-free period is short (70-80 days) and depends on the altitude of area. During the warm period (April-October), $140 \mathrm{~mm}$ of precipitation falls. In winter, $55-70 \mathrm{~mm}$ of precipitation falls. In the mountains, the amount of precipitation is much higher and reaches 500$600 \mathrm{~mm}$ per year [4].

The research area belongs to the slope-deluvial solifluction type of mountain tundra terrain on solid permafrost rocks. The volumetric ice content of the complexes is 0.2-0.4 unit fraction [7]. The temperature of rocks at the subface of stratum of a layer of annual variations ranges from $-3.0--8.0^{\circ} \mathrm{C}$. The predominant cryogenic textures and deposit forming ice found within this type of terrain are layered, lenticular, and transection. The main cryogenic processes on the territory include thermokarst, heaving, and thermal erosion [7].

The soils of the study zone are alluvial swamped, meadow-bog and taiga gleyed peaty-humus, peculiar to poorly broken, undulating plains of the lower reaches of the East Billekh to the height of 200-270 m A.S.L., as well as the valley of the Yana River and its main tributaries.

According to the phytogeographical zoning [4], the territory belongs to the North taiga subzone of the taiga 
zone of Yakutia occupied by a strip of rare lowland, mountain larch woods.

According to the classification of Kuzin P.S. [8] the Ilin-Billekh belongs to the Middle-Yana area. The rivers are poorly studied. The average height of the area is 400 m.

The water balance of the Middle-Yana area can be roughly characterized by the following indicators: precipitation is $250 \mathrm{~mm}$; runoff $-150 \mathrm{~mm}$, evaporation $100 \mathrm{~mm}$, runoff coefficient [4] is about 0.60 .

The water regime of rivers is characterized by harsh summer and autumn floods with a maximum in mid-June and a long, steady freezing over. The duration of ice formation is approximately 8 months (the streams considered freeze to the bottom). And summer floods exceed the flood in occasional years. The summer water level is low [5].

Spring flooding usually occurs in the second half of May after establishing positive average daily air temperatures. The maximum rise in water level reaches in the first half of June. Its duration is 30-40 days [5]. Maximum flow modules on rivers with catchment areas of $1000 \mathrm{~km}^{2}$ or more can reach $300 \mathrm{l} / \mathrm{sec}$. [5]. The observed maxima are 30-50 times higher than the average annual runoff. The summer-autumn flood period lasts from 60 to 100 days. During the summer and autumn period, about $50 \%$ of annual flow takes place on the rivers.

The largest number of floods per year can reach 5-7 times. Modules of the highest floods on the rivers with the specified catchment areas $\left(1000 \mathrm{~km}^{2}\right)$ can reach up to $200 \mathrm{l} / \mathrm{s}$ in summer and up to $60 \mathrm{l} / \mathrm{s}$ in autumn. In interflood periods, the average modules of dry-weather flow can be estimated at about $1 \mathrm{l} / \mathrm{sec}$.

In the arid Verkhoyansk depression, the rivers are very low-water. The volume of high water does not exceed 10-15 $\mathrm{mm}$ there, and the annual flow - 40-50 $\mathrm{mm}$. The maximum flooding modules of summer floods on rivers with catchment areas of $500-600 \mathrm{~km}^{2}$ are 100 $1 / \sec [5]$.

The Ilin-Billekh originates from the lake of Kumakh. It is a right tributary of the Yana River and flows into it at $744 \mathrm{~km}$ from its mouth. The river is $62 \mathrm{~km}$ long. The catchment area is $630 \mathrm{~km}^{2}$. Fig. 2 .

As the most promising for the first-priority construction of microelectric power plants, the hydroelectric power station No. 2 at $24 \mathrm{~km}$ from the mouth was considered. For the high-altitude justification of hydrometric works, a ground control point was set $-\mathrm{a}$ working permanent bench mark with a relative mark of $100 \mathrm{~m}$, Fig.2. The terrain marks were defined by leveling on the slope of the banks from the water's edge to the highest flood level.

As a result of hydrometric work, data on the depth of the stream, the area of water section, water flow, and the slope of water surface are obtained. The profile of the hydraulic solution is constructed.
The water consumption on the Ilin-Bellekh at the above-mentioned stream gauge is $4,27 \mathrm{~m}^{3} / \mathrm{s}$

Average speed $\mathrm{V}_{\mathrm{cp}}=0.56 \mathrm{~m} / \mathrm{s}$.

Conclusions: 1. The cutoff one of the numerous bends in the lower reaches of the Ilin-Billekh will create a difference in the height of water levels [5].

2. On the Ilin-Billekh, even with low water content, the power of microelectric power plants can be $30-40$ $\mathrm{kW}[5]$.

The Dzhuganja. The research was conducted in Tomponsky ulus of the Republic of Sakha (Yakutia), three kilometers northeast of the village of Topolinoye. The village is a center of the Tomponsky nasleg. It is located on the left bank of the Tompo River.

The population as of 01.01 .2018 is 909 people. The main productions are reindeer husbandry, fishing, and huntibg of fur animals.

The research object is a cross section section of lower course of the Dzhuganja, the left tributary of the Tompo River which flows into the Aldan River. Fig. 3.

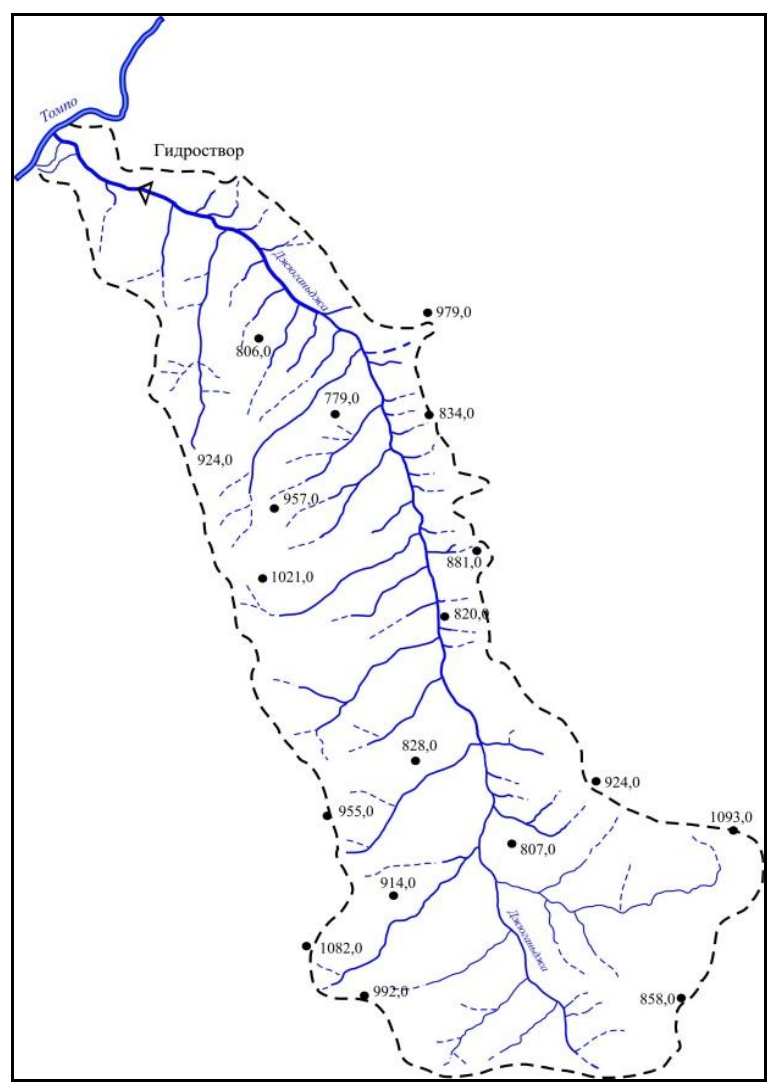

Fig. 2. The catchment scheme of the Dzhuganja

The main orographic element of the territory is the Verkhoyansky ridge. It is a bending fold with predominance of mid-mountain alpine type terrain with strongly dissected mountain peaks reaching $1673 \mathrm{~m}$ and deeply-entrenching valleys of mountain streams [4].

Not far from this place there is the Northern border of the Sette-Daban range, which is $450 \mathrm{~km}$ long. The territory is composed by the complex of slope deposits.

The climate of the territory is sharply continental with long cold winter (up to 7 months). Minimum temperatures in winter reach $-60^{\circ} \mathrm{C}$. Summer is short and 
warm. The maximum temperature reaches $+38^{\circ} \mathrm{C}$ in summer.

The average annual precipitation is $284 \mathrm{~mm}$. The minimum amount of precipitation falls on January, and the maximum is on July.

The site is located in the mountain-valley type of terrain of intrazonal North taiga types of landscape on solid permafrost rocks with underflow taliks, at the Northern end of the meridionally extended Sette-Daban mid-mountain province. The type of permafrost landscapes is widely represented throughout the territory of North-East and South Yakutia.

The temperature of annual variations on the subface of stratum here is $-2.0--5.0^{\circ} \mathrm{C}$. The thickness of seasonal thaw depth varies widely from 0.3 to $2.7 \mathrm{~m}$, the most likely interval is $0.7-1.8 \mathrm{~m}$. The volume ice content of sand and gravel complexes is $25-45 \%$. The prevailing cryogenic textures and deposit-forming ice on the territory are stratus, lenticular, reticulate (peat, loam, sandy loam), massive, crusted (sand-and-gravel), sometimes low-power polygonal wedge ice. The main cryogenic processes include frost cracking, thermokarst, and heaving [6].

The soils of the area are permafrost floodplain peatand peat-boggy with areas of sod-forest and meadowboggy soils. Here, larch open and light forests with areas of chosenia and poplar forests, dwarf arctic birches and cotton grass bogs. The cross section terrain is represented by intrazonal forests of poplars stretching along the lower reaches of the Dzhuganja.

The Dzhuganja is a left tributary of the Tompo River. It is $41 \mathrm{~km}$ long. It flows into the Tompo River at 280 $\mathrm{km}$ from the mouth. The catchment area is $204 \mathrm{~km}^{2}$, and there are no lakes in the basin.

According to the classification of Kuzin P.S. [8] it is included in the area of the Verkhoyano-Kolymsk mountain arc.

The quantitative characteristic of the water balance of the Verkhoyano-Kolymsky district is determined by the following data: precipitation of $500 \mathrm{~mm}$, runoff of $350 \mathrm{~mm}$, evaporation of $150 \mathrm{~mm}$, average runoff coefficient of 0.70 [4]. The water regime of the district's rivers is characterized by low and spring flood with a maximum in mid-June, summer and autumn floods that exceed spring flood in some years. The summer water level is high, and the winter water level is low. The period of ice cover is long.

In the first half of May in the southern parts of the district the mountain streams begin to open. In the North, the ice break comes in the second half of this month. In mid-June, there is a maximum of high water. Its duration is from 50 to 80 days. The total volume of water during this period increases from 120 to $300 \mathrm{~mm}$. The volume of annual runoff is $200 \mathrm{~mm}$. About $60 \%$ of the annual runoff flows during high water period [5].

The period of icing-rainfall runoff lasts from two to three months; the total volume of this runoff is on average about $150 \mathrm{~mm}$ or about $35 \%$ of the annual runoff. 5-6 floods occur during the summer-autumn period and only on some rivers the number of floods increases to 7-9 (the Eastern Khandyga and the Ebetem rivers) [5].

The formation of floods is influenced mainly by three factors. First, permafrost thaws to a small depth in a short warm season which creates favorable conditions for relatively rapid saturation of grounds with water. Secondly, it is not uncommon for precipitation to fall in the form of continuous rains for several days with small interruptions. Precipitation of many days, as a rule, creates high moisture content of the thawed layer of soil and subsoil in which even small amounts of precipitation form floods. And, finally, third, low precipitation is accompanied by heavy rains and downpours with daily precipitation totals of 50 to $100 \mathrm{~mm}$ or more.

Average winter runoff modules are mostly $0.2 \mathrm{l} / \mathrm{sec}$. In winter, at an average of $5 \%$ of the annual runoff flows down. The duration of winter ice cover is about 8 months [5].

As a result of field measurements of elements of the hydrological regime and calculations on the Dzhuganja the following values were established. Table 1.

Table 1. Hydrometric characteristics of the Dzhuganja

\begin{tabular}{|l|l|}
\hline Hydrological indicators & $\begin{array}{l}\text { Field } \\
\text { measurements }\end{array}$ \\
\hline $\begin{array}{l}\text { Overall consumption of water } \\
\text { between verticals }\end{array}$ & $0,2031 \mathrm{~m}^{3} / \mathrm{s}$ \\
\hline Discharge section area & $0,7291 \mathrm{~m}^{2}$ \\
\hline Width of river in line & $5,35 \mathrm{~m}$ \\
\hline Cross section mean deep & $0,14 \mathrm{~m}$ \\
\hline
\end{tabular}

According to the above guidelines the following values are set:

The Dzhuganja: $\mathrm{F}=204 \mathrm{~km}^{2}, \mathrm{Q}_{\text {ср.год. }}=1.43 \mathrm{~m}^{3} / \mathrm{s}$, $\mathrm{H}=10 \mathrm{~m}$. For the derivational HPP, the flow rate $\mathrm{Q}=0.72$ $\mathrm{m}^{3} / \mathrm{s}$ and $\mathrm{H}=10 \mathrm{~m}$ is accepted. And then the power $\mathrm{N}_{\text {ycr }}=55 \mathrm{~kW}$.

Waterbodies: the Desovsky, the Stantsiya streams, the Setyndzha River. These objects are located in the immediate vicinity of the village of Sebyan-Kyuel of Kobyaisky ulus of the Republic of Sakha (Yakutia) at a distance of 2.5-4.0 km. Fig. 4. 


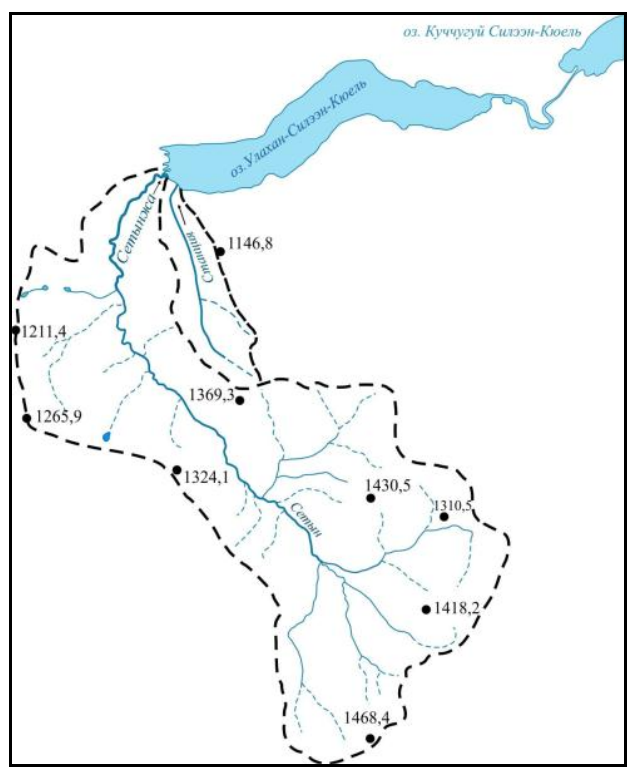

Fig.4. Sketch map of the Setyndzha river and stream Stantsiya

In physical and geographical terms, the territory under consideration belongs to the Verkhoyansk tundrataiga infolded low-mountain and middle mountain reliefs [4].

Sluggish rivers with meandering channels have wide swampy valleys. There are lakes of oxbow and thermokarst type of glacial origin - Ulakhan-SileenKuyel, Kuchugui-Sileen-Kuyel and others. Mountain rivers are characterized by deep-cut, canyon-like valleys [6]. The difference of marks of lake Ulakhan-SileenKuyel (759 m a.s.l. BS) with adjacent mountain hills is from 600 to $900 \mathrm{~m}$. The height of the gorge cut by the stream in this area is about $10 \mathrm{~m}$. The valley floor is made up of rubbly and pebbly material.

In winter, the weather in the valleys is usually dry, windless, and with little snow. In the mountains in winter, there is a strong temperature inversion. Despite the increase in temperature with altitude, the severity of weather in the mountains increases sharply compared to the valleys.

Summer is cold, the frost-free period is very short (Syuren-Kuyel - 38 days) or completely absent. Along with rains, there are snowfalls. The annual precipitation is $286 \mathrm{~mm}$ (Syuren-Kuyel) with $264 \mathrm{~mm}$ falling during the warm period (April-October), and only $22 \mathrm{~mm}$ falling during the cold period. The height of the snow cover here reaches $33 \mathrm{~cm} \mathrm{[5].}$

In the permafrost-landscape relation, the study sites are located in the Priverkhoyansk moraine province in two types of localities.

The first type of terrain is an intrazonal glacier-valley type of terrain with mountain taiga on solid permafrost soils with underflow taliks. It is characterized by glacial genetic stratigraphic sequence. Lenticular, cortical, and basal (rubbly and pubbly) deposit-forming ice predominates among the cryogenic textures. Volume ice content is $25-40 \%$. The main cryogenic processes are the frost cracking and thermokarst. The temperature on the subface of stratum of annual variations is $-2.0--5.0^{\circ} \mathrm{C}$. The thickness of the seasonal thawing layer is from 0.7 to $1.8 \mathrm{~m} \mathrm{[7].}$

The second type of terrain is high-altitude zoned mountain-slope with mountain sparsely wooded areas on solid permafrost layers. It is composed of a complex of slope deposits and bedrock. This type of terrain is characterized by layered, lenticular, basal, reticulated, fractured (original) cryogenic textures and depositforming ice, ice of bald peaks (coarse-grained). Volume ice content can vary from 25 to $65 \%$. The main cryogenic processes are cryogenic weathering, rock glaciers, solifluction, and cryogenic creep. The temperature of rocks on the subface of stratum of annual variations is $-2.0--9.0^{\circ} \mathrm{C}$. The thickness of the seasonally thawing layer is from 0.6 to $1.8 \mathrm{~m} \mathrm{[7].} \mathrm{The}$ soils of the area are permafrost floodplain peat- and peatswamp with areas of sod-forest and meadow-marsh.

According to the phytogeographical zoning, the territory is located in the zone of the Northern larch taiga with sections of chosenia and poplar forests, dwarf arctic birches and cotton grass bogs on permafrost floodplain peat- and peat-bog soils with sections of sod-forest and meadow boggy soils.

The Desovsky stream is a tributary of the Momyia River. According to the classification of P.S. Kuzin [8], the stream belongs to the area of the VerkhoyanoKolymsky mountain arc. It is underground-fed stream. On the right bank of the stream there is a ledge overgrown with sparsely wood, then higher up the slope turns into a rocky mountain slope. The left bank of the stream has almost smooth surface passing in the floodplain of the Momyia [5]. The total width of the valley of the Momyia and the Desovsky in this cross section is about $500 \mathrm{~m}$.

To perform hydrometric work on the stream, two stream gauges were selected. Table 2 shows the depth and area of cross section of the stream Desovsky in stream gauge 1 and 2 .

Table 2. Hydrometric characteristics of the stream Desovsky in stream gauge 1 and 2

\begin{tabular}{|l|l|}
\hline Hydrological indicators & $\begin{array}{l}\text { Field } \\
\text { measurements }\end{array}$ \\
\hline Discharge section area & $0,0265 \mathrm{~m}^{2}$ \\
\hline Width of river in line & $0,4000 \mathrm{~m}$ \\
\hline Cross section mean deep & $0,066 \mathrm{~m}$ \\
\hline $\begin{array}{l}\text { Water velocity of the Stantsiya river } \\
\text { in stream gauge 1 }\end{array}$ & $0,39 \mathrm{~m} / \mathrm{s}$. \\
\hline Water consumption & $0,01 \mathrm{~m}^{3} / \mathrm{s}$ \\
\hline
\end{tabular}

Conclusions. As can be seen from the table below, the Desovsky is not promising for the construction of a priority small hydroelectric power station.

The Stantsiya stream which flows into the Momyia River is a tributary of the Yana of the fourth order [10] $400 \mathrm{~m}$ from the mouth. The Stantsiya stream is located 4 
$\mathrm{km}$ from the village of Sebyan-Kuyel and has a length of $7 \mathrm{~km}$ and a catchment area of $6.9 \mathrm{~km}^{2}$.

According to the classification of P.S. Kuzin [8] as well as the Dzhuganja and the Desovsky streams the Stantsiya belongs to the area of Verkhoyansk-Kolyma mountain arc. The stream's valley is gorge-like.

In Table 3 the water depth, cross-section area, and flow rate of the stream Stantsiya are shown.

Table 3. Hydrometric characteristics of the stream Stantsiya

\begin{tabular}{|l|l|l|}
\hline Hydrological indicators & \multicolumn{2}{|l|}{ Field measurements } \\
\hline & $\begin{array}{l}\text { Stream } \\
\text { gauge 1 }\end{array}$ & $\begin{array}{l}\text { Stream } \\
\text { gauge 2 }\end{array}$ \\
\hline Discharge section area & $0,1360 \mathrm{~m}^{2}$ & $0,776 \mathrm{~m}^{2}$ \\
\hline Width of river in line & $1,0 \mathrm{~m}$ & $2,4 \mathrm{~m}$ \\
\hline Cross section mean deep & $0,14 \mathrm{~m}$ & $0,32 \mathrm{~m}$ \\
\hline $\begin{array}{l}\text { Overall consumption of water } \\
\text { between verticals }\end{array}$ & $0,080 \mathrm{~m}^{3} / \mathrm{s}$ & $0,2821 \mathrm{~m}^{3} / \mathrm{s}$ \\
\hline
\end{tabular}

The installed capacity of a small hydroelectric power station on the stream Stantsiya with a maximum water flow $\mathrm{Q}=0.069 \mathrm{~m}^{3} / \mathrm{s}$ and water head $\mathrm{H}=40 \mathrm{~m}$ will be 20 $\mathrm{kW}$.

The Setyndzha River is good for the installation of a micro-power plant. The tributary of Lake UlakhanSileen Kuyel is $17 \mathrm{~km}$ long and has a catchment area of $72.0 \mathrm{~km}^{2}$.

to

The power of MPP on the Setyndzha River is equal

$$
\mathrm{N}=9,81 * \text { КПД*Q*H }=9,81 * 0,8 * 0,35 * 40=109,9
$$
$\mathrm{kW}$

\section{Conclusions}

Thus, a small hydroelectric power station on the Setynja River can be used only during summer high water and spring floods while the Setyndzha River is the most suitable watercourse for considering the possibility of installing a small hydroelectric power station. On September the water consumption was approximately 1 $2 \mathrm{~m}^{3} / \mathrm{s}$.

\section{References:}

[1] Hydrotechnical Bureau. [Electronic resource].URL: https://www.gidroburo.ru/index.php/aproektirovanie/a-4-malye-ges/44-a-4-06-raschetmoshchnosti-malykh-ges (reference date: 02.03.2020)

[2] Determination of the main calculated hydrological characteristics, SP33-101-2003M.:Gosstroy of Russia. 2004.73

[3] Engineering and hydrometeorological surveys for construction. SP11-103-97-M.: Gosstroy of Russia. 2001. 29 p.

[4] S. S. Korzhuev. Yakutia. Institute of Geography of Siberia and the Far East. - M.: Nauka, 1965. - 467 p.
[5] D.D. Nogovitsyn, Z.M. Sheina, L.P. Sergeeva. «On the possibility of using hydroelectric power of small rivers of Yakutia». Advances in modern natural science. № 12. 2017. P. 221-225.

[6] R.I. Protopopov, A. M. Truschelev, G.Kh. Protopopov, S.S. Fedorova, L.P. Zharikova et al. State geological map of the Russian Federation. Scale 1:1 000 000. Verkhoyano-Kolyma series. Sheet Q-53 Verkhoyansk. Explanatory note. - SPb.: Kartographicheskaya fabrika VSEGEI, 2015. 437 p. +9 incl.

[7] M.N. Zheleznyak, Cryogenic-landscape map of the RS (Yakutia). Scale 1:1500000. RAS SB the Melnikov Institute of the Permafrost. 2017.

[8] P.S. Kuzin. Classification of rivers and hydrological zoning of the USSR. L.: Gidrometeoizdat, 1960. - $455 \mathrm{p}$.

[9] Climate: Topolinoye [Electronic resource]. URL: $\quad$ http://ru.climate-data.org/location/323530/ (reference date: 23.07.2019)

[10] Search for data from the state water register [Electronic resource]. URL:http://www.textual.ru/gvr/index.php?card=255991 $\& \mathrm{bo}=0 \& \mathrm{rb}=0 \& \mathrm{subb}=0 \&$ hep $=0 \&$ wot $=0 \&$ name $=\% \mathrm{CC} \%$ $\underline{\mathrm{EE} \% \mathrm{EC} \% \mathrm{FB} \% \mathrm{FF} \& \mathrm{loc}}=$ (reference date: 02.03 .2020$)$ 